\title{
INVESTIGATION OF PEDAGOGICAL CONDITIONS FOR DEVELOPMENT OF PROFESSIONAL SELF-PERFECTION SKILLS OF FUTURE AGRICULTURAL ENGINEERS
}

\author{
Stanislav Nikolaenko ${ }^{1}$, Maria Bondar ${ }^{1}$, Oksana Bulgakova $^{2}$, Ilmars Dukulis ${ }^{3}$ \\ ${ }^{1}$ National University of Life and Environmental Sciences of Ukraine, Ukraine; ${ }^{2}$ Institute of History of \\ Ukraine, National Academy of Sciences of Ukraine, Ukraine; ${ }^{3}$ Latvia University of Life Sciences and \\ Technologies, Latvia \\ vbulgakov@meta.ua, ilmars.dukulis@1lu.lv
}

\begin{abstract}
The engineer of modern agricultural production is obliged to improve himself, that is, to have persistent skills in creative professional self-training. The investigations were conducted within two Engineering faculties of the National University of Life and Environmental Sciences of Ukraine, as well as the Engineering Faculty of the Latvia University of Life Sciences and Technologies. Achievement of the goals in the educational and cognitive activities of the future engineers depends on how fully the conditions of modern agricultural production, as well as the objective pedagogical conditions that determine the difficulty of the objects of study are considered. One of the main tasks of the formation of the readiness of the future agricultural engineers for professional activities and self-development in the process of teaching general engineering disciplines is the use of methods to enhance educational and professional activities. An efficient mechanism for the improvement of the educational process is the close cooperation of universities with the agricultural employers, and their involvement in the formation and implementation of the programmes, specialties and specialisations, coordination with them of educational and professional standards of modern engineering training. From the surveys the most significant skills to achieve the goals of independent educational and scientific activity of the future engineers were identified - this is the ability to find, analyse and interpret information in the process of educational and scientific activity, and- a skill to pursue a healthy way of life, to work efficiently, to spend one's free time in a rational manner.
\end{abstract}

Keywords: engineering training, motivation, training, self-development.

\section{Introduction}

Agricultural production has turned into one of the most efficient sectors of economy; here expensive and rapidly changing machinery in terms of complexity is used. The engineering workers in the sphere of agricultural production should not only possess engineering knowledge and skills, but also be prepared for independent and creative their application and perfection. In addition, the task of creating conditions that ensure continuous development of the professional potential of the student's personality comes to the foreground. In psychological and pedagogical scientific works, there are increasingly studied problems, associated with the need to increase the level of cognitive independence of the students, which as a result, are transformed into a readiness for professional activity and professional self-improvement [1]. The quality level of training of the future engineers not fully meets the needs of modern production and directly depends on their interest and participation in the practical and research work in their chosen specialty [2].

Unfortunately, insufficient attention is paid to the participation of practicing agricultural engineers in the educational process of a higher educational institution. Cooperation of the engineering departments with the potential employers is also fairly useful from the point of finding possible sources of strengthening the material base of educational and research laboratories, which, considering the high cost of the modern equipment, is extremely important for the improvement of the training quality of the engineering personnel. It is known that the students, studying general engineering disciplines, have difficulties associated with the complexity of understanding and insufficient motivation for independent analysis of technical objects and processes [2]. Often the students have no need to doubt the correctness of the models of the process proposed in the educational literature that are studied, and, as a result, the need to improve the professional training of the future engineers is diminishing; since the basic theoretical base is unchanged, there are objective laws of mechanics, and therefore there is no need for additional research and refinement. That is why the quality level of training of the future agroengineers does not fully meet the requirements of modern agricultural production, and it directly depends on their interest and participation in the practical and research work in their chosen specialty [3]. In psychological and pedagogical scientific works there are most often investigated the problems associated with the need to increase the level of cognitive independence of 
the students, which, as a result, are transformed into a readiness for professional activity and professional self-improvement [4]. Rahman K., when examining the problems of self-improvement, concludes that individuals who are engaged in self-improvement differ from the people who are not engaged in self-improvement by the factors of the life success and entrepreneurial characteristics. It was established by investigations that they have more leadership responsibilities and autonomy at work, and they have a higher income than the people who are not looking for self-improvement [5]. Antonacopoulou E., examining the impact of initiatives of the employee's development upon their readiness and orientation to training and development, concludes: the concept of self-development is based on the assumption that the individual is able to take the responsibility that self-development entails. The mechanisms, used to support the development of the employees in organisations, should take into account the expectations of individual people as a necessary part of the learning process. No less important is the need to reconsider the way of thinking, recognising that this is a complex and multifaceted process that needs to be studied [6]. It is within the framework of training that the adaptive processes for the future professional activities should take place [7]. The future engineer should feel a constant need for self-education and should be able to put it into practice when working at the enterprise [8-9]. In the opinion of most researchers, the enhancement of the students' independent work and intensification of their educational and cognitive activities were and are extremely useful for their further self-improvement in the future production activities. So, already Dewey J. (the founder of pedagogical pragmatism) suggested that the focus in training be centred on independent work. His main idea was that training should be conducted by independent solution of the problems by the students, arising in their practice [10].

In his publications, Zhuk O. arrives at a conclusion that the engineering education in the United States provides broad, not a highly specialised training, and, according to experts, its orientation should be problematical, rather than disciplinary. That is - the training of comprehensively developed (universal) specialists, prepared for continuous improvement of their qualifications. Based on this, the authors believe that the study of the American experience in the use of the teaching methods of engineering students is relevant for the higher engineering education [11]. In a study by Meichner H.E. it is noted that a man in the process of passive perception will remember $10 \%$ of what he has read, $20 \%$ of what he has heard, $30 \%$ of what he has seen, $50 \%$ of what he has seen and heard; and, with active perception, $80 \%$ of what they say themselves and $90 \%$ of what they do or create on their own [4]. Confirming this position, Luzan P.G notes: “... according to the activity approaches, acquisition of the content of the historical experience of the people proceeds not due to the transfer of information about it to a person, but in the process of his own activity, aimed at objects and phenomena of the surrounding world ..." [12]. Shaposhnikova I. states that "... the tendencies to change the paradigm of the educational systems are in the plane of search for such options where each personality has not only prepared for social adaptation in a fast flowing environment and is adapted to the needs of the epoch but also outruns by his spiritual development the outdated models of the world perception of the older generations..." [13]. Consequently, the future engineer must perceive a significant amount of information, comprehend it and, on the basis of the acquired knowledge, be ready to independently solve new, even more complex problems. Then he will fulfil his potential to a maximum degree and will be competitive in the labour market.

The purpose of the work is the study of pedagogical conditions for the development of professional self-improvement skills of the future agricultural engineer.

\section{Materials and methods}

The investigations were conducted within two engineering faculties of the National University of Life and Environmental Sciences of Ukraine (NULES), as well as the Engineering Faculty of the Latvia University of Life Sciences and Technologies. The basic primary information was obtained by questionnaire survey and interviewing, according to well-known classical methods. One of the goals of the study was the desire to find out how fully the pedagogical conditions in creating the educational environment for efficient individual independent work of the students of various educational levels of the engineering faculties of Ukraine's NULES were maintained.

Undergraduate students-bachelors from the engineering faculties of full-time studies took part in the investigation, - 175 people, and the first and second year students, studying for the Master's 
degree - 115 people, total - 290 people. Next, the database of the students' survey was used to study the problems of forming their ability to control independent educational and cognitive activities. To assess the level of satisfaction with the professional training of the engineering graduates, a total of 674 people were interviewed at the NULES, of which 54 were represented by the agrobusiness management $(8 \%)$; the graduates, engineers of different spheres and levels of agricultural production -256 people $(38 \%)$; scientific workers -74 people $(11 \%)$; 175 students-bachelors of the engineering faculties $(26 \%)$; the master students from the engineering faculties $-115(17 \%)$.

The investigation was conducted in two stages. As the goal of the first stage of the study was selected the need to find out how the employers and the practicing engineers, on the one hand, and the scientific and pedagogical workers, on the other hand, are satisfied with the training quality of graduates of the engineering faculties. The respondents were asked to evaluate how the engineering training of the young specialist corresponds to the requirements of modern production, that is, whether the engineering training is: 1) impeccable; 2) in general, good; 3) satisfactory; 4) not entirely satisfactory; 5) bad. An analysis was performed of the current provisions of the legislative and regulatory base that affect the problems associated with the development of creative technical thinking and the formation of engineering knowledge and skills; scientific research, methodological and specialised literature on the problems of the formation of the motivational-value and professionalinstrumental spheres of the future agricultural engineer. The domestic and foreign experience of using technologies of personal development training was generalised; a survey was conducted; interviews were held with employers, practicing engineers, teachers, and students with the aim to improve training of engineers for the spheres of agricultural engineering and production operations. Questionnaires were processed using mathematical and statistical methods: to identify a statistically trustworthy relationship in the indicators for the assessment of the professional and personal qualities that a graduate needs for successful adaptation in the production - analysis of the correlation matrices (processing in the SPSS); to identify statistically significant rank correlations - the Spearrman method of rank correlations; to test the selected structural components of the pedagogical conditions for the formation of skills for professional self-training and self-improvement - the Student t-test for independent variables), for the calculation of indicators and building diagrams (processing in the Statistica 6 and MS Excel 2010).

\section{Results and discussion}

Agricultural production has turned long ago into one of the most efficient sectors of economy, and it maintains a stable trend of dynamic development. The consequences of errors in the operation of high-performance and high-value agricultural machinery affect in the most dramatic way the success of agrobusiness. The engineer of modern agricultural production, by virtue of the above circumstances, is simply obliged to improve himself, that is, to have persistent skills in creative professional self-training.

Surveys of the employers-graduates from the engineering faculties revealed a significant common problem of the domestic higher engineering education, manifested in the imperfection of the interaction of universities with the labour market, which puts forward new requirements at the present stage of production relations - there is an urgent need for universal specialists, being in command of foreign languages, information technology, ready to quickly grasp the intricacies of the specifics of a particular field of engineering activities, having the skills of efficient engineering management [14]. The involvement of the employers in the educational process of the engineering faculties of the university has a number of positive aspects. In order to ensure high quality of professional training of specialists, on the basis of complex cooperation with the interested organisations - the leading employers, by combining the intellectual potential, material, financial and corporate resources of the partners, the Council of the Employers of the NULES of Ukraine was established, and a convent of advisers was set up at the Latvia University of Life Sciences and Technologies. They are the coordinator of cooperation of the faculties with the employers, which occurs within the framework of the organisation and implementation of the training-educational and scientific research process, the logical conclusion of which is the employment of the university graduates and their further successful work in the chosen specialty. The structural-logical diagram of the goals and directions of cooperation between the engineering faculties and the employers is presented in Fig. 1. 


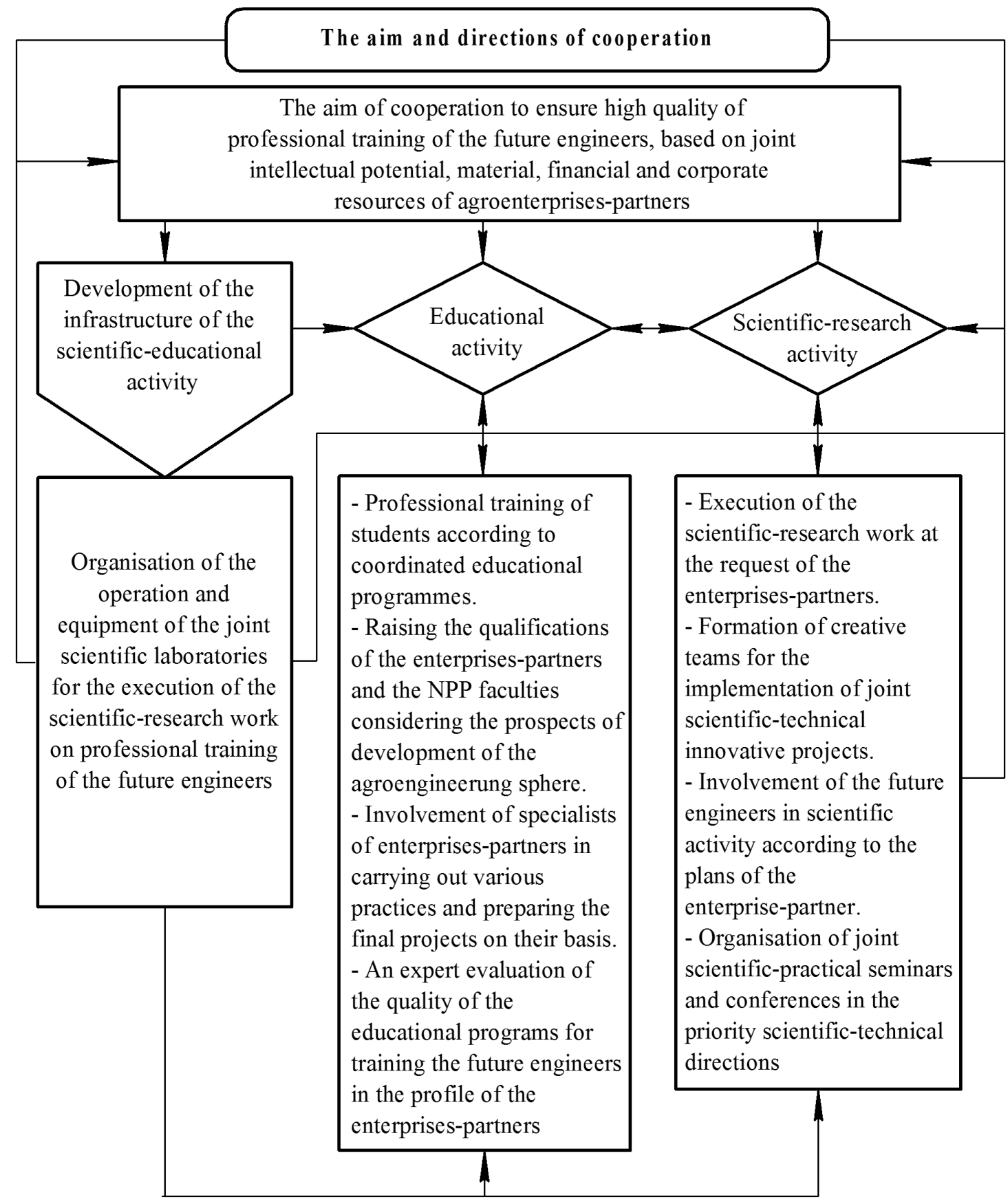

Fig. 1. Structural-logical scheme of cooperation between the engineering faculties of the university with the employers and agrobusiness in the process of the improvement of engineering training of the graduates

When forming the content of the directions of cooperation between the employers, agrobusiness and the engineering faculties in the field of training the engineering personnel, contradictions were established between the related systems and trends, namely, between: 1) a clear trend in accelerated spread of the science-intensive innovative technologies in mechanical engineering, and insufficiently high readiness of the graduates of the engineering faculties to solve professional problems; 2)the need to strengthen the level of the fundamental general engineering training of the future specialists, and the real state of their readiness for professional self-development; 3 )the reproductive substantive nature of the educational process, and the integrated creative nature of the activities of a modern engineer in the machine-building industry or in the responsible field of operation of expensive agricultural equipment. 
In several stages, during the 2015-2019 academic years, when performing professional orientation, at the meetings of the graduates, various working meetings and scientific and production conferences, there were organised questionnaire surveys and inquiries of the participants: the representatives of the business, production and operation of the agricultural machinery, as well as the teachers and university students. The results of the evaluation of the satisfaction level with the professional training of the graduates of engineering specialties are summarised in the histogram, shown in Fig. 2. The study revealed that $70.3 \%$ of respondents recognised the professional training of the graduates as meeting the production requirements, and $29.7 \%$ of respondents were not satisfied with the quality of the engineering training.

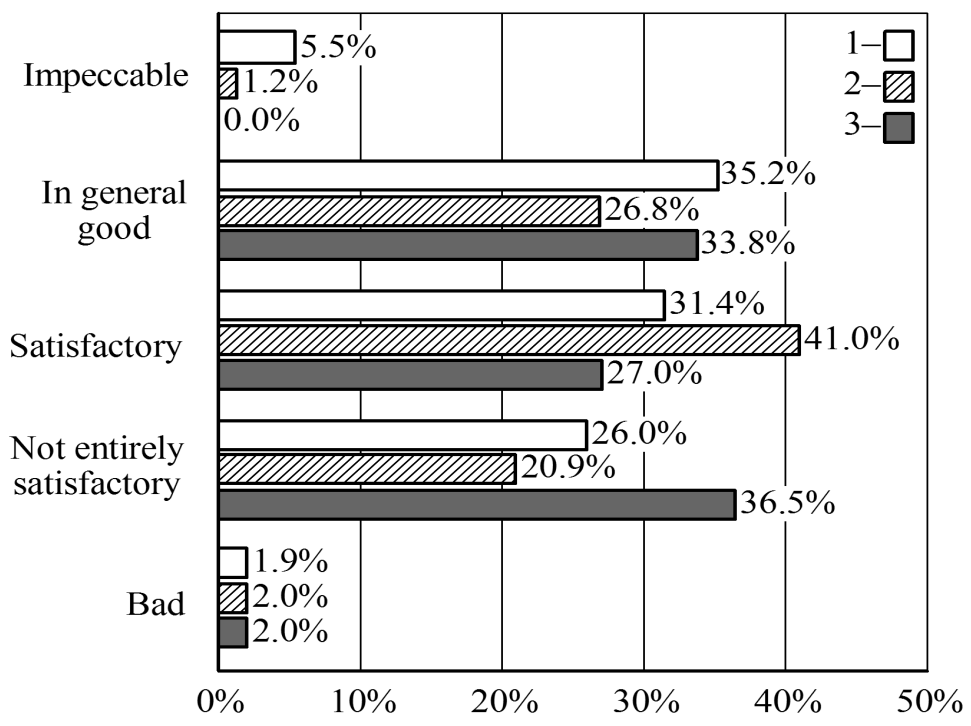

Fig. 2. Evaluation of the satisfaction level with the professional training of the graduates of engineering specialties: 1 - the agrobusiness management 54 people; 2 - the graduates, practicing engineers of various spheres and levels of agroproduction -256 people; 3 - scientific and scientific-pedagogical workers -74 people

One of the aims of the study was the need to establish the professional and personal qualities that are necessary for a graduate to adapt successfully to production. The employers' opinion about the main positive qualities and skills that are necessary for a young specialist-engineer to successfully adapt to production was studied by a questionnaire method where it was suggested to evaluate the proposed personality qualities, arranged in alphabetical order on a five-point scale: perseverance in achieving the goal; possession of a sense of responsibility; industry; confidence in one's strength; good communication skills. And the professional qualities of a specialist, also in alphabetical order: knowledge of foreign languages; technical skills in one's specialty; deep professional knowledge; practical experience; readiness for professional self-development. The results of this questionnaire are summarised in Table 1. When analysing the results of the questionnaire, a conclusion was arrived at that the main of the suggested personal qualities, necessary for the graduate, are "possession of a sense of responsibility" $-35.2 \%$ and "industry" $-30.0 \%$, then approximately equally followed: "good communication skills" - $11.9 \%$; "persistence in achieving the goal" - $11.8 \%$; "self-confidence" $11.2 \%$. In determining the professional qualities that are necessary for a future agricultural engineer for successful adaptation in production, preference is given to the "formation of readiness for professional self-development" - $42.9 \%$ of the surveyed employers, production representatives, scientific and scientific-pedagogical workers; $23.3 \%$ - "deep theoretical knowledge"; $13.5 \%$ chose "knowledge of foreign languages"; almost equal to "possession of practical experience" and "possession of technical skills in the specialty", respectively $-10.2 \%$ and $10.0 \%$. In order to develop in oneself a professional, the graduate of an engineering faculty must not only deeply master professional knowledge and skills but also, which is not less important, be prepared for constant selfeducation and self-development under the changing conditions of modern production. 
Table 1

Comparative table of evaluation of the professional and personal qualities that are necessary for a graduate to successfully adapt in production

\begin{tabular}{|c|c|c|c|}
\hline $\begin{array}{c}\text { Personal qualities that are necessary } \\
\text { for a graduate to successfully adapt in } \\
\text { production }\end{array}$ & $\begin{array}{l}\text { Agrobusines } \\
\text { s } \\
\text { management }\end{array}$ & $\begin{array}{c}\text { Graduates, engineers } \\
\text { of various spheres and } \\
\text { levels of agricultural } \\
\text { production }\end{array}$ & $\begin{array}{l}\text { Scientific and } \\
\text { scientific- } \\
\text { pedagogical } \\
\text { workers } \\
\end{array}$ \\
\hline \multicolumn{4}{|c|}{ Personal qualities that are necessary for a young specialist } \\
\hline Perseverance in achieving the goal & $16.7 \%$ & $9.1 \%$ & $9.5 \%$ \\
\hline Possession of a sense of responsibility & $46.3 \%$ & $34.9 \%$ & $24.3 \%$ \\
\hline Industry & $25.9 \%$ & $37.2 \%$ & $27.0 \%$ \\
\hline Confidence in one's strength & $3.7 \%$ & $10.9 \%$ & $18.9 \%$ \\
\hline Good communication skills & $7.4 \%$ & $7.9 \%$ & $20.3 \%$ \\
\hline \multicolumn{4}{|c|}{ Professional qualities hat are necessary for the young specialist } \\
\hline Knowledge of foreign languages & $5.5 \%$ & $14.8 \%$ & $20.3 \%$ \\
\hline $\begin{array}{l}\text { Possession of technical skills in one's } \\
\text { specialty }\end{array}$ & $9.3 \%$ & $15.2 \%$ & $5.4 \%$ \\
\hline Deep professional knowledge & $20.4 \%$ & $19.9 \%$ & $29.7 \%$ \\
\hline Practical experience & $5.5 \%$ & $10.3 \%$ & $14.9 \%$ \\
\hline $\begin{array}{c}\text { Readiness for professional self- } \\
\text { development }\end{array}$ & $59.3 \%$ & $39.8 \%$ & $29.7 \%$ \\
\hline
\end{tabular}

During the survey, from the proposed list, it was necessary to choose the most significant, according to respondents, organisational conditions for efficient independent work of the students. Second, to choose the skills that have a decisive impact upon the results of achieving the goals of independent educational and scientific activities of the future engineers. The results of the study are summarised in Figures 3 and 4. In the graphs below the total number of responses exceeds the number of the participants, since respondents were allowed to choose up to three variants of the response.

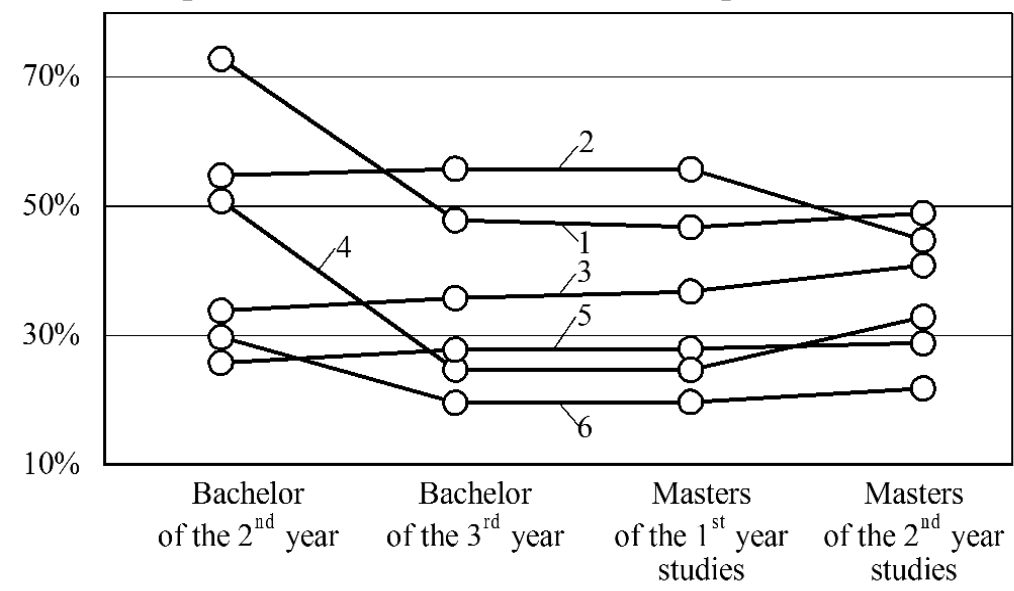

Fig. 3. Evaluation of the most significant, according to the students, organisational conditions promoting independent educational and scientific activities of the future engineers:

1 - organisation of obtaining complete and concrete information about the expected individual independent work, the requirement for its implementation; 2 - organisation of the workplace, provision of quality scientific and methodological literature for the students' individual independent work; 3 - organisation of systematic consultations with the scientific-pedagogical workers of the chairs; 4 - a possibility of self-control of the knowledge in a remote operation mode by means of specially worked out tests; 5 - organisation of objective, unbiased evaluation of the performed independent work; 6 - access to the result of control 
When analysing the results of a students' survey, there is a noticeable difference in the opinions of the students of the junior and senior years of studies, which can be explained by personal experience gained in performing the independent work in the senior years of studies. Most second year students of the bachelor's studies believe that, in order to organise independent studies, they need to have complete and specific information about the upcoming individual work, about the requirements for its implementation, indicating the list of tasks and the time allotted for their implementation. While the third-year bachelors and the first-year masters gave preference to the organisation of the workplace and the provision of scientific and methodological literature for individual independent work. The need for systematic consultations with scientific and pedagogical workers of the chairs has an almost stable trend with a small growth dynamics. When performing individual independent tasks that require a creative, professional approach in finding ways how to solve them, it is important that the scientific and pedagogical workers have the skills to implement the counselling process. The results of a survey of the students' evaluative views on the most significant skills that have an essential impact upon the achievement of the goals of the independent educational and scientific activities of the future engineers are presented in Fig. 4.

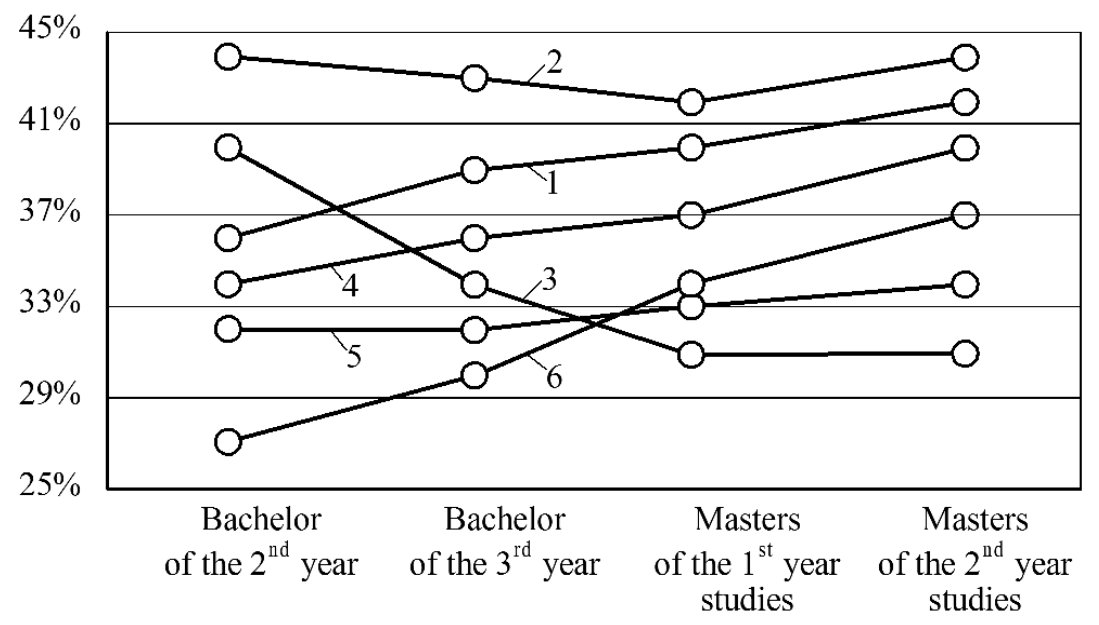

Fig. 4. Assessment by students of the most significant skills that have a decisive impact upon achieving the goals of independent educational and scientific activities of the future engineers: 1 - a skill to pursue a healthy way of life, to work efficiently, to spend one's free time in a rational manner; 2 - a skill to find, analyse and interpret information in the process of the educational and scientific activity; 3 - a skill to determine correctly the amount of the independent work that could be accomplished during the allotted period of time; 4 - a skill to identify the determining positions of the independent work that require most attention; 5 - a skill to match the performed work with the preset one; 6 - a skill to analyse and form conclusions

From the surveys the most significant skills to achieve the goals of independent educational and scientific activity of the future engineers were identified - this is position " 2 ": the ability to find, analyse and interpret information in the process of educational and scientific activity, and position "1" - a skill to pursue a healthy way of life, to work efficiently, to spend one's free time in a rational manner were collected $-44 \%$ and $42 \%$ of the answers, respectively. As important there is recognised the acquired ability to identify the defining positions of independent work that require the most attention (position "4") - continuous growth from $34 \%$ to $40 \%$. A generalised conclusion on the study of students' attitudes toward independent work suggests that achieving efficiency in shaping the readiness of the graduates of engineering faculties for professional self-development is possible under the conditions of a mandatory individual approach and providing stimulation of the graduates' professional growth, fostering creative activity and initiative.

\section{Conclusions}

1. There is obtained a comparative assessment of the professional and personal qualities that are necessary for a graduate to successfully adapt in production. Preference is given to the "formation of readiness for professional self-development" $-42.9 \%$ of the surveyed employers, production 
representatives, scientific and scientific-pedagogical workers; $23.3 \%$ - "deep theoretical knowledge"; $13.5 \%$ chose "knowledge of foreign languages"; almost equal to "possession of practical experience" and "possession of technical skills in the specialty", respectively $-10.2 \%$ and $10.0 \%$.

2. Achievement of the goals in the educational and cognitive activities of the future engineers depends on how fully the conditions of modern agricultural production, as well as the objective pedagogical conditions that determine the difficulty of the objects of study are considered.

3. An efficient mechanism for the improvement of the educational process is the close cooperation of universities with the agricultural employers, and their involvement in the formation and implementation of the programmes, specialties and specialisations, coordination with them of educational and professional standards of modern engineering training.

\section{References}

[1] Nikolaenko S., Bulgakova O., Dukulis I., Pilvere I. methodological aspects of theoretical training of the future agroengineers. Engineering for Rural Development, Proceedings, Vol. 18, 2019, pp. 1933-1940.

[2] Кузнецов Ю.М. Опыт развития научно-технического творчества молодежи в Киевском политехническом институте имени Игоря Сикорского. Современное образование доступность, качество, признание. Сборник научных трудов XI Международной научнометодической конференции (Experience in the development of scientific and technical creativity of youth at the Igor Sikorsky Kiev Polytechnic Institute. Modern Education Accessibility, Quality, Recognition: Collection of scientific papers of the XI International Scientific and Methodological Conference), Краматорск, 2019, pp. 98-101. (In Russian)

[3] Baltusite R., Briede B. Implementation of findings of generation theories in engineering studies, Engineering for Rural Development, Proceedings, Vol. 17, 2018, pp.1078-1083

[4] Novotny J. Physical principles in technical education. Engineering for Rural Development, Proceedings, Vol. 17, 2018, pp.1002-1005.

[5] Rahman K. Self-improvement efforts and success in life and work. [online] [21.01.2020]. Available at: https://www.researchgate.net/publication/316172976_Self-improvement _efforts_and_success_in life_and_work

[6] Antonacopoulou E. Employee development through self-development in three retail banks. [online] [21.01.2020]. Available at:

https://www.researchgate.net/publication/238325137_Employee_development_through_selfdevelopment_in_three_retail_banks

[7] Баклицкий И.О. Психологические особенности учебной мотивации студентов (Psychological features of educational motivation of students) [online] [21.01.2020]. Available at: http://www.nbuv.gov.ua/Portal/Soc_Gum/Nvldu/2008_2/baklyckyjio.pdf

[8] Terlou K. Trends Changing the Space of Educational Technology: A Challenge to Higher Education [online] [21.01.2020]. Available at: http://www.hse.ru/news/media/63841790.html

[9] Vintere A. Study on engineering students experience in mathematics learning in context of sustainable development, Engineering for Rural Development, Proceedings, Vol. 17, 2018, pp.1186-1191.

[10] Дьюи Д. Опыт и образование. (Experience and education), Львов: Кальвария, 2003, 84 p. (In Ukrainian).

[11]Жук О.И. Профессиональная подготовка инженеров в США: традиции и инновации. Сборник научных трудов Хмельницкого института социальных технологий Университета «Украина» (US Engineer Training: Traditions and Innovations. Collection of scientific papers of the Khmelnitsky Institute of Social Technologies of the University of Ukraine). Хмельницкий: ХИСТ, No 2, 2013, pp. 83-87. (In Ukrainian).

[12] Лузан П.Г. Активизация обучения в сельскохозяйственном вузе (Intensification of education at an agricultural university). Киев: Институт аграрной экономики УААН, 1996. 188 р. (In Russian)

[13]Шапошникова И.М. Тенденции перестройки системы подготовки учителя начальных классов. Подготовки учителя начальной школы в условиях новой парадигмы образования: материалы Международной. научно-методологической конференции (Trends in the 
restructuring of the primary school teacher training system. Preparing an elementary school teacher in a new education paradigm: Proceedings of scientific and methodological conference), Киев, 2004, pp. 77-80. (In Ukrainian).

[14] Работодатели студентам: надежность сельскохозяйственной техники в системе инновационных процессов (Employers to students: the reliability of agricultural machinery in the system of innovative processes). [online][11.02.2020] Available at: https://nubip.edu.ua/node/66957 (In Russian) 